\title{
MODELING OF REFRACTANCE WINDOW FILM DRYER FOR LIQUIDS
}

*Ghanem, T.H.

\section{ABSTRACT}

The aim of the present study is to develop mathematical analysis of a film dryer or refractance type dryer that helps in design, operation, modification, evaluating drying time and rates, improving quality and increasing energy efficiency. Strawberries juice was used as an example of liquid foods. For justifying this purpose a pilot plant refractance window dryer was designed. A film of juice with an initial thickness of approximately $3 \mathrm{~mm}$, was applied on a hot glass plate heated by water underneath, that continuously contacts it. Nine experiments were conducted, namely: three variable flow rates per unit surface area of the dryer, $0.25,0.21$ and $0.18 \mathrm{~m}^{3} / \mathrm{m}^{2} . \mathrm{s}$, and also three different levels of heating rates for each flow rate were also applied, i.e. 15.2, 24.3 and $36.6 \mathrm{~kW} / \mathrm{m}^{2}$ respectively. Liquid strawberries drying time ranged between 0.77-0.90 h compared to $5 \mathrm{~h}$ for traditional hot-air dryer at $60{ }^{\circ} \mathrm{C}$. The model is reasonably accepted for predicting the drying coefficient-elapsed time product and moisture ratio with coefficients of determination of $97 \%$.

\section{INTRODUCTION}

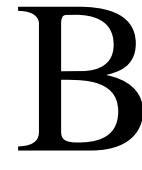

Rendan et al. (1999) in their project compared the following pilot plant dryers namely: refractance window, drum, spray and freeze dryers, using energy efficiency, Beta carotene, total carotene, ascorbic acid(vitamin C) and color retention of strawberries and carrots. They reported that the choice of strawberries and carrots was due to their importance as a source of vitamin $\mathrm{C}$ and pro-vitamin A (B-carotene) respectively. They summarized their results as follows:

1. Energy efficiencies 27.9-47.6\% obtained for different drying conditions for the refractance window system were comparable to or slightly higher than the hot air methods(30-40\%) reported in the literature.

*Assoc. Prof., Agric. Eng.. Fac. of Agric., Al-Azhar Univ. 
2. Vitamin $\mathrm{C}$ retention in refactance window dried sraberries were comparable to or higher than freeze-dried to a similar moisture content.

3. Beta-, Alpha and total carotene retention of refractance window dried carrots were comparable to freeze dried product and better than drumdried products.

4. Color degradation in refractance window dried products was comparable to or slightly less than that of freeze dried products.

Feng et al.(1999)reported that the drying kinetics in refractance window system for tested liquid foods generally followed the trend obtained for similar products using other drying methods, with no apparent constant rate period. Lin and Agalloco (1979) reported that dried strawberries may be stored in a long time and used in the preparation of many products, such as jams, and Jellies, bakery products and serials. They added that the main factors responsible for rapid degradation of ascorbic acid include temperature, $\mathrm{PH}$, Oxygen concentration, light intensity, liquid in which the ascorbic acid is stored, presence of metal ions, and the initial ascorbic acid concentration. They also concluded that the drying curves obtained contained more than one falling rate periods. Sjoholm (1982) studied drying rate curves, heat and mass transfer coefficients and Nuselt number for a combined convective and conductive drying on a laboratory scale. The transfer area was $0.3 \times 0.3 \mathrm{~m}$ was formed by a metal block. Conductive heating was obtained by circulating water in the metal block and convective heating was by preheating the circulated air. He added that the material to be dried was in the form of a film with an initial thickness of $1-1.5 \mathrm{~mm}$. He also reported that this equipment allows the optimization of drying process with regard to nutritional properties and energy consumption. He also mentioned this technique is useful for foodstuffs with low heat stability with regard to the preservation of vitamins, enzymes or other heat sensitive products in the biotechnological industry. Gehrmann (1979) studied heat and mass transfer coefficients for convective drying of gelatine applied on glass disc. He reported that the constant rate period was not obtained. Dennis and Singh (1981) reported that the knowledge of the complex drying mechanisms in food products is still imperfect in estimating drying time, theoretically derived expressions 
are useful only in obtaining rough estimates. They added that experimental trials to predict drying time are most appropriate where possible.

\section{THEORITICAL APPROACH}

The first step in the similitude application is to define the most associated variables affecting the investigated phenomena. The following are the pertinent and independent variables considered to affect the drying coefficient-elapsed time product:

\begin{tabular}{|c|c|l|c|c|}
\hline NO. & Symbol & \multicolumn{1}{|c|}{ Description } & Dimension & Units \\
\hline 1 & $\mathrm{~K}$ & Drying coefficient & $\mathrm{t}^{-1}$ & $\mathrm{~h}^{-1}$ \\
\hline 2 & $\phi$ & Elapsed time of drying & $\mathrm{t}$ & $\mathrm{h}$ \\
\hline 3 & $\lambda$ & Characteristic length & $\mathrm{L}$ & $\mathrm{m}$ \\
\hline 4 & $\mathrm{v}$ & Air flow rate per unit surface area & $\mathrm{Lt}^{-1}$ & $\mathrm{~m} / \mathrm{s}$ \\
\hline 5 & $\mathrm{q}$ & Heating rate & $\mathrm{Ht}^{-1}$ & $\mathrm{~kJ} / \mathrm{s}$ \\
\hline 6 & $\mathrm{~m}_{\mathrm{p}}$ & Mass of material being dried & $\mathrm{M}$ & $\mathrm{kg}$ \\
\hline 7 & $\mathrm{C}_{\mathrm{p}}$ & Specific heat of material & $\mathrm{HM}^{-1} \theta^{-1}$ & $\mathrm{~kJ} / \mathrm{kg} .{ }^{0} \mathrm{~K}$ \\
\hline 8 & $\Delta \mathrm{T}$ & $\begin{array}{l}\text { Temperature difference } \\
\text { between top and bottom of the } \\
\text { material being dried }\end{array}$ & $\theta$ & ${ }^{\circ} \mathrm{K}$ \\
\hline 9 & $\mathrm{R}$ & $\begin{array}{l}\text { Relative humidity of the drying } \\
\text { rate. }\end{array}$ & Dimensionless \\
\hline
\end{tabular}

The general relationship for the drying coefficient-elapsed time product and moisture ratio as a function of the associated independent variables can be expressed as:

$\mathrm{K} \phi=\mathrm{F}\left(\lambda, \mathrm{v}, \mathrm{q}, \mathrm{m}_{\mathrm{p}}, \mathrm{C}_{\mathrm{p}}, \Delta \mathrm{T}, \mathrm{R}\right)$

According to the Buckingham Pi-theorem, the number of dimensionless and independent quantities required to express a relationship among the variables in any phenomenon is equal to the number of quantities involved, minus the number of dimensions of those quantities Murphy (1950). In the present study nine quantities with five dimensions are involved. So, four dimensionless groups can be formed. The dimensional analysis yields the following relationships for dryer: 


$$
\begin{aligned}
& \mathbf{K} \boldsymbol{\phi}=\mathbf{F}\left\{\left(\frac{\lambda}{\mathbf{v} \boldsymbol{\phi}}\right)\left(\frac{\mathbf{m}_{\mathbf{p}} \mathbf{c}_{\mathbf{p}} \Delta \mathbf{T}}{\mathbf{q} \boldsymbol{\phi}}\right) \mathbf{R}\right\} \\
& \mathbf{K} \phi=\mathrm{A}\left(\frac{\lambda}{\mathbf{v} \phi}\right) \ldots \ldots \ldots \ldots
\end{aligned}
$$

Where $\mathrm{A}$ and $\mathrm{C}$ are functions of $\pi_{3}$. It is notable that $\pi_{2}$ represents the circulation parameter of the drying air. $\pi_{3}=\left[\mathrm{m}_{\mathrm{p}} \mathrm{C}_{\mathrm{p}} \Delta \mathrm{T} / \mathrm{q} \phi\right]$ represents the energy efficiency or the ratio between useful heat used in drying process and the available heating rate. Relative humidity is approximately constant due to high velocity of the drying air i.e. 2 to $1.4 \mathrm{~m} / \mathrm{s}$.

\section{MATERIALS AND METHODS}

In the present study, a pilot plant refractance window dryer type was designed and tested in the Agricultural Engineering Department Faculty of Agriculture Al-Azhar University Nacr City.

\section{Film dryer construction:}

The dryer as shown in Fig.(1), consists of a water basin of four sides of galvanized iron sheet of $0.5 \mathrm{~mm}$ thick. The basin dimensions are $0.4 \mathrm{x} 0.4$ $\mathrm{m}$, and was insulated from its bottom and sides by $0.03 \mathrm{~m}$ polyurethane panels. The space above the basin (dryer bin) is completely tight by a transparent cover tightly from the bottom. The outer surface of the dryer basin is tightly covered with insulated steel cover. A $2 \mathrm{~kW}$ heater, thermostat and an indicator circuit was used for controlling the water temperature in the basin. Basin water was continuously compensated by an apparatus maintaining the water at the atmospheric pressure.

\section{Measuring instrumentations:}

1 Thermocouples :Temperatures were measured using type-K thermocouples, multiple channel switch for the same thermocouple type to prevent compensation. The output device includes a large 4-digits temperature reading display and electronic circuitry, the specifications of thermocouples are U.S.A manufactured, model 8528-40, full accuracy $18-28^{\circ} \mathrm{C}$ and useful range $4-45^{\circ} \mathrm{C}$

2 Turbo meter: A turbo meter was used for measuring the drying air speed in $\mathrm{m} / \mathrm{s}$. It is manufactured in U.S.A, measuring ranges: $0-44.8 \mathrm{~m} / \mathrm{s}$. 3-Relative humidity: Measured by hygrometers 1-100 \% , made in Germany. 
4-Electrical balance: Made in Japan, Sartorius type , accuracy $0.0001 \mathrm{~g}$.

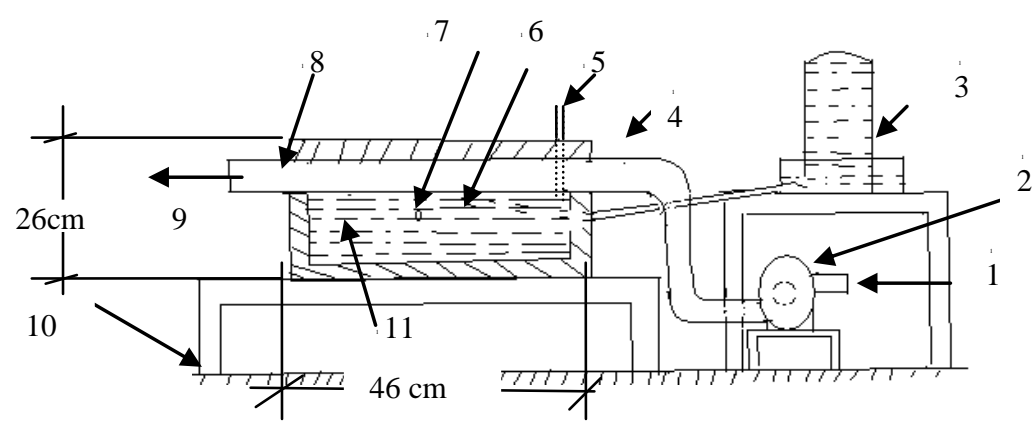

1Air inlet.

2 Electrical air blower.

3 Controlling water pressure apparatus.

4 Air duct.

5 Water vent.

6 Water inlet.
7 Electrical heater and thermostat.

8 Dryer space.

9 Air outlet.

10 Table.

11 Heated water.

Fig(1)Experimental setup of the film drying system.

\section{METHODS}

Nine experiments were conducted namely: three variable flow rates per unit surface area of the dryer, $0.25,0.21$ and $0.18 \mathrm{~m}^{3} / \mathrm{m}^{2}$.s , and also three different levels of heating rates for each flow rate were also applied i.e. $15.2,24.3$ and $36.6 \mathrm{~kJ} / \mathrm{m}^{2}$.s respectively. A film of juice with an initial thickness of approximately $3 \mathrm{~mm}$, was applied on the dryer space.

\section{Moisture - content determination:}

The moisture content was determined according to AOAC (1990). Four different samples were taken for evaluating the moisture content of strawberries.

\section{Dryer mass balance}

The dryer mass balance concept was used for the determination of mass reduction during a period of $\phi$ to $\phi+\Delta \phi$ as follows:

$$
\mathrm{m}_{\mathrm{p}}(\phi+\Delta \phi)=\mathrm{m}_{\mathrm{p}}(\phi)\left(1-\mathrm{M}_{\mathrm{wb}}(\phi)\right) /\left(1-\mathrm{M}_{\mathrm{wb}}(\phi+\Delta \phi)\right.
$$

$\mathrm{m}_{\mathrm{p}}(\phi)$ : is the initial mass of strawberries being dried; $\mathrm{kg}$, $\mathrm{m}_{\mathrm{p}}(\phi+\Delta \phi)$ :is the mass of strawberries being dried after time increment of $\Delta \phi ; \mathrm{kg}$; 
$\mathrm{M}_{\mathrm{wb}}$ : is the moisture content of strawberries \% wet basis.

\section{Available heating rate $q \mathrm{~kW}$ :}

Available heating rate was evaluated at equilibrium state of the dryer without neither air flow nor strawberries liquid film based on the three modes of heat transfer i.e. conduction $\mathrm{q}_{\mathrm{k}}$, convection $\mathrm{q}_{\mathrm{c}}$ and radiation $\mathrm{q}_{\mathrm{r}}$ in $\mathrm{kW}$ from hot water through the glass plate respectively, which can be represented as follows:

\section{Conduction through the glass plate:}

$$
\mathbf{q}_{\mathbf{k}}=\mathrm{A}(\mathrm{Tw}-\mathrm{Tg}) /\left(\mathrm{L}_{\mathrm{g}} / \mathrm{K}\right) \text {. }
$$

Convection through air above the glass plate:

$$
\begin{array}{r}
\mathrm{q}_{\mathrm{c}}=\mathrm{hc} \mathrm{A}\left(\mathrm{T}_{\mathrm{g}}-\mathrm{T}_{\mathrm{a}}\right) \ldots \ldots \\
\mathrm{h}_{\mathrm{c}}=2.4493\left(\mathrm{~T}_{\mathrm{g}}-\mathrm{T}_{\mathrm{a}}\right)^{0.25}
\end{array}
$$

Radiation from hot water to the glass cover:

$$
\mathrm{q}_{\mathrm{r}}=\varepsilon \sigma \mathrm{A}\left(\mathrm{T}_{\mathrm{w}}{ }^{4}-\mathrm{T}_{\mathrm{g}}{ }^{4}\right) / \mathrm{Ah}_{\mathrm{r}}\left(\mathrm{T}_{\mathrm{w}}-\mathrm{T}_{\mathrm{g}}\right) .
$$

$\mathrm{T}_{\mathrm{w}}$ : is the Water temperature ${ }^{\circ} \mathrm{K}$,

$\mathrm{T}_{\mathrm{g}}$ : is the glass plate temperature, ${ }^{0} \mathrm{~K}$,

$\mathrm{K}$ : thermal conductivity of glass plate $\mathrm{kW} / \mathrm{m} .{ }^{\circ} \mathrm{K}$,

$\mathrm{h}_{\mathrm{c}}$ : is convection heat transfer coefficient $\mathrm{kW} / \mathrm{m}^{2.0} \mathrm{~K}$,

$\mathrm{h}_{\mathrm{r}}$ :is radiation heat transfer coefficient $\mathrm{kW} / \mathrm{m}^{2.0} \mathrm{~K}$,

$\varepsilon_{\mathrm{g}}:$ is the emittance of the glass cover;0.9 Rai(1980),

$\sigma$ : is Stefan-Boltzman constant, $5.6697 \times 10-5 \mathrm{~kW} / \mathrm{m}^{20} \mathrm{~K}^{4}$;

$\mathrm{Lg}_{\mathrm{g}}$ : is the glass plate thickness, $0.003 \mathrm{~m}$.

$A:$ is the surface area of the dryer $\mathrm{m}^{2}$.

\section{Hydrulic radius or characteristic length $\lambda$ in " $m$ ":}

The characteristic length of the drying bin is determined as follows:

$$
\lambda=4 \mathrm{~A} / \mathrm{p}
$$

$\mathrm{A}:$ is the dryer surface area $\mathrm{m}^{2}$; 
$\mathrm{P}:$ is the perimeter of the drying bin " $\mathrm{m} "$.

$$
\mathrm{P}=21+\mathrm{L}
$$

$1:$ is the thichness of the strawberry film being dryed;

$\mathrm{L}$ : is the dryer bin length " $\mathrm{m}$ ".

\section{Specific heat of strawberries $C_{p} \mathrm{~kJ} / \mathrm{kg}^{0} \mathrm{C}$ :}

The specific heat of strawberries was evaluated as a function of water and solid contents according to Toledo (1991):

$$
\mathrm{C}_{\mathrm{p}}=4.1868 \mathrm{M}_{\mathrm{wb}}+0.83736\left(1-\mathrm{M}_{\mathrm{wb}}\right) \text {. }
$$

\section{Drying coefficient determination:}

Drying coefficient was determined by plotting the logarithm of moisture ratio MR against elapsed time for all experiments.

$$
\mathrm{MR}=\left(\mathrm{M}-\mathrm{M}_{\mathrm{e}}\right) /\left(\mathrm{M}_{\mathrm{o}}-\mathrm{M}_{\mathrm{e}}\right)
$$

Where $\mathrm{M}, \mathrm{Me}$ and Mo are moisture content at any time,equilibrium moisture content and initial moisture content $\%$ wet basis respectively.

\section{RESULTS AND DISCUSSIONS}

The present study was conducted to develop mathematical analysis of a film dryer or refractance type dryer for drying strawberries juice as an example of liquid foods, and can be used also for tomato's juice and other heat sensitive products which are approximately similar to strawberries as reported by Jean and penington (1994). Large size of film dryers is beneficial for drying heat sensitive products in the biotechnological industry as tomato's juice, especially when the demand is highly decreased and huge amounts of tomato are available, which in turn forces farmers to till the product into the ground due to its trifle price. Refraction window dryer has the advantage of reducing drying time $(0.77-0.90 \mathrm{~h}$ compared to $5 \mathrm{~h}$ for traditional hot- air dryer at $60{ }^{\circ} \mathrm{C}$ ) as depicted in table(1) and higher drying rates due to several mechanisms of heat transfer controlling the drying process i.e. conduction, convection and radiation. Also drying air is at ambient temperature that helps in optimization of the drying process with regard to nutritional properties and energy consumption. Fig (2) shows drying coefficient determination by plotting the logarithm of moisture ratio against elapsed time for 0.25 $\mathrm{m}^{3} / \mathrm{m}^{2}$.s and $15.2 \mathrm{~kJ} / \mathrm{m}^{2}$.s. Fig.(3) shows relations between $\pi_{1}$ and $\pi_{2}$ for the nine experiments when $\pi_{3}$ varied from $2.79 \times 10^{-2}$ to $1.001 \times 10^{-2}$, 
logarithmic relations were reasonably justified with coefficient of determination ranging between 0.95 to 0.93 . Fig. (4) shows relationships between the $\mathrm{A}$ and $\mathrm{C}$ parameters in equation (2) as affected by $\pi_{3}$ are also logarithmic justified as follows:

$$
\mathbf{A}=\mathbf{0 . 4}\left(\frac{\mathbf{m}_{\mathbf{p}} \mathbf{p}_{\mathbf{p}} \Delta \mathbf{T}}{\mathbf{q} \boldsymbol{\phi}}\right)^{\mathbf{0 . 1}}
$$

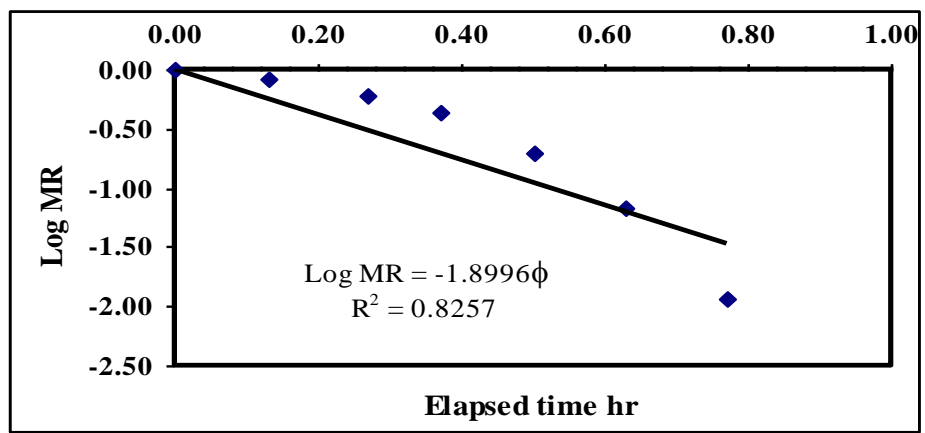

Fig.(2) Drying coefficient determination.

$$
\mathbf{C}=\mathbf{0 . 6}\left(\frac{\mathbf{m}_{\mathbf{p}} \mathbf{c}_{\mathbf{p}} \Delta \mathbf{T}}{\mathbf{q} \phi}\right)^{\mathbf{0 . 0 7}}
$$

Fig.(5) shows observed and predicted values of the drying coefficient-elapsed time product with coefficient of determination of 0.97. Fig.(6) also declared that the complete prediction equation is reasonably accepted for predicting the moisture ratio, the following form is justified:

$$
M R=e^{-0.4}\left(\frac{m_{p} c_{p} \Delta T}{q \phi}\right)^{0.1}\left(\frac{\lambda}{v \phi}\right)^{0.6}\left(\frac{m_{p} c_{p} \Delta T}{q \phi}\right)^{0.07}
$$

\section{SUMMARY AND CONCLUSION}

The aim of the present study is to develop mathematical analysis of a film dryer or refractance type dryer that helps in design, operation, modification, evaluating drying time and rates, improving quality and increasing energy efficiency. Strawberries juice was used as an example of liquid foods. From the present study we can concluded that: 


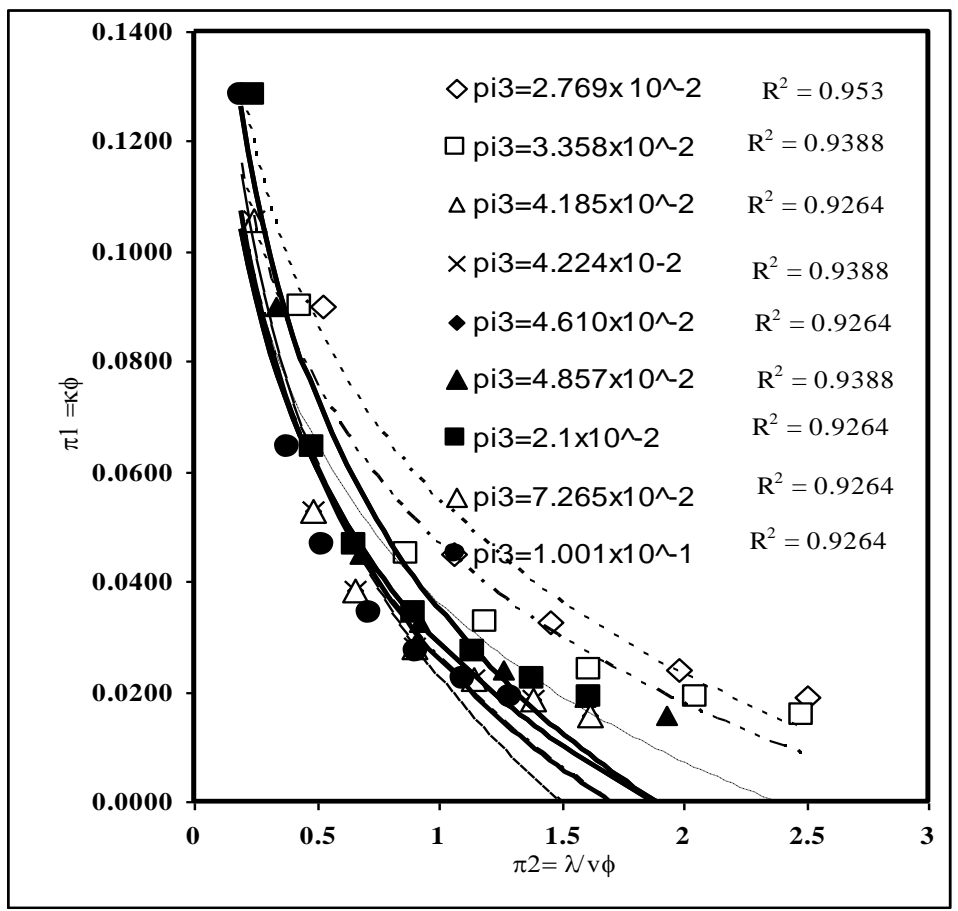

Fig(3) Relationship between $\mathrm{p} 1, \mathrm{p} 2$ and $\mathrm{p} 3$ varied from $2.769 \times 10-2$ to $1.001 \times 10-1$.

1 Drying rates are highly affected by air flow rates, hydraulic radius, heating rates, specific heat and temperature difference between top and bottom of the product being dried.

2 The prediction equation for drying coefficient-elapsed time product and moisture ratio is reasonably accepted with coefficients of determination

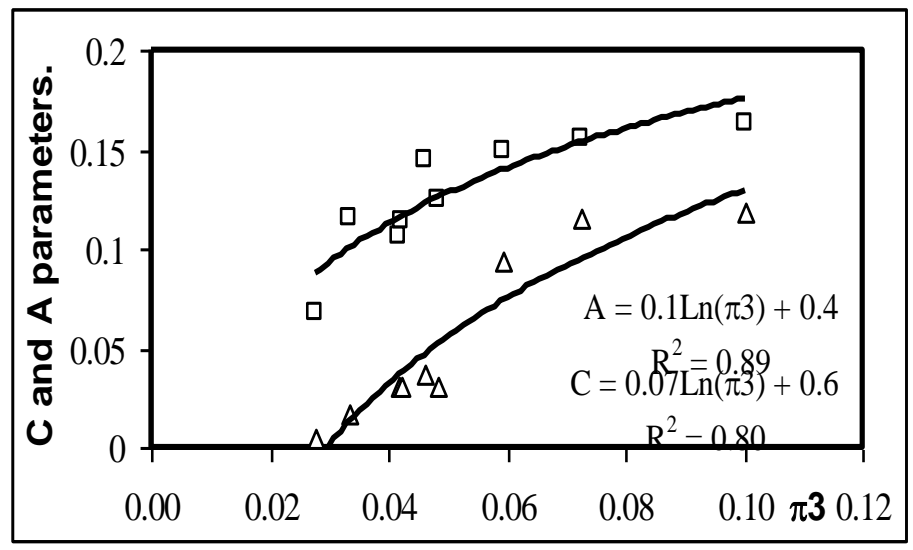

Fig.(4) Relationship between A, C parameters and $\pi 3=m_{p} C_{p} \Delta T / q \phi$. 


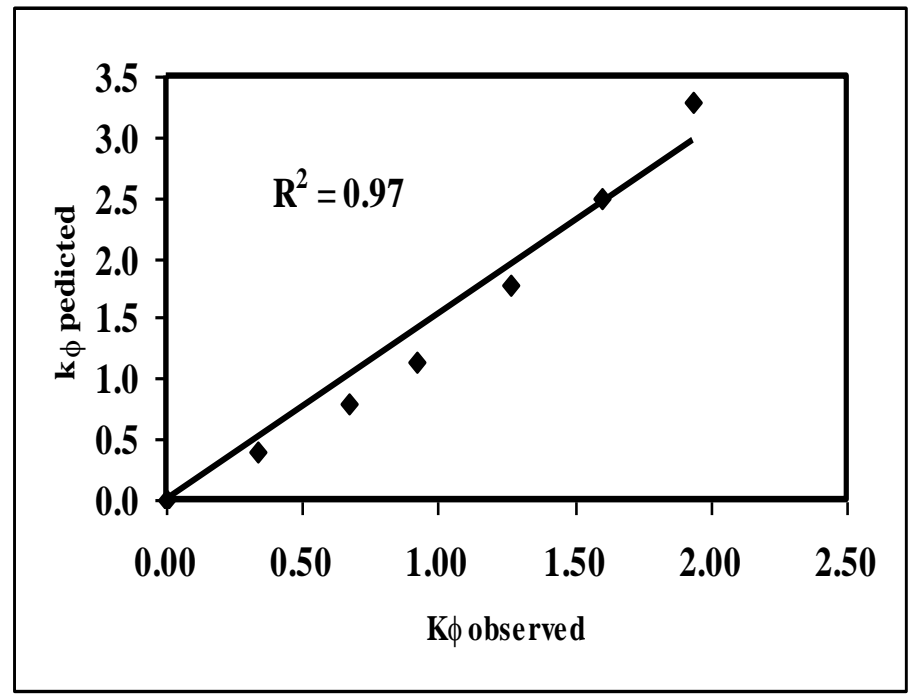

Fig(5) Observed and predicted values of $k \phi$.

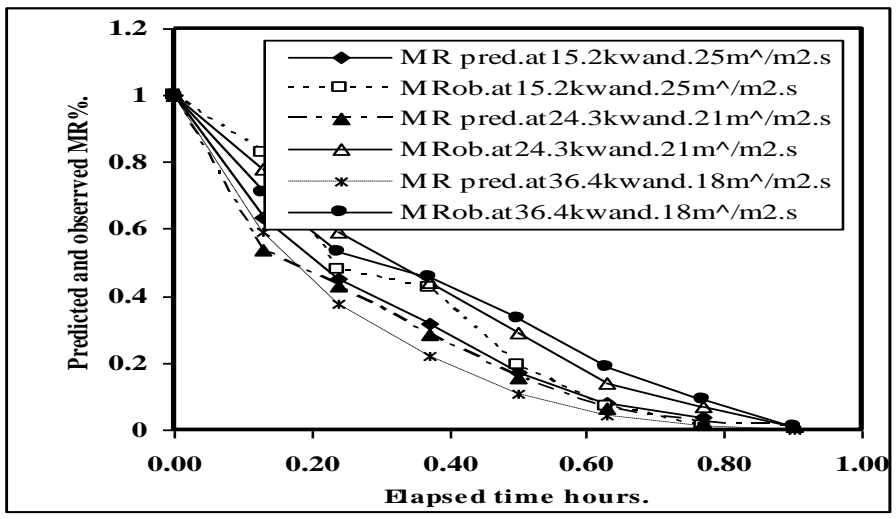

Fig.(6).Predicted and observed miosture ratio "MR" as affected by drying time.

of $97 \%$. The predicted equation was of the form:

$$
M R=e\left(\frac{m_{p} c_{p} \Delta T}{q \phi}\right)^{0.1}\left(\frac{\lambda}{v \phi}\right)^{0.6}\left(\frac{m_{p} c_{p} \Delta T}{q \phi}\right)^{0.07}
$$

Where MR is the moisture ratio, $\mathrm{m}_{\mathrm{p}}$ is the mass of product being dried "kg" , $\mathrm{Cp}$ is the specific heat of the product " $\mathrm{kJ} / \mathrm{kg}^{\circ} \mathrm{C} ", \Delta \mathrm{T}$ is the 
temperature difference between surface and bottom of the product being dried ${ }^{\circ} \mathrm{C}, \lambda$ is the hydraulic radius, $\mathrm{v}$ is the air flow rate per unit surface area of the dryer $\mathrm{m}^{3} / \mathrm{m}^{2}$.s and $\mathrm{q}$ is heating rate " $\mathrm{kW}$ ".

3- Liquid strawberries drying time ranged between $0.77-0.90 \mathrm{~h}$ compared to $5 \mathrm{~h}$ for traditional hot-air dryer at $60{ }^{\circ} \mathrm{C}$.

4- Large size of film dryers are beneficial for drying heat sensitive products in the biotechnological industry as tomato's juice especially when the demand is highly decreased and huge amounts of tomato are available, which in turn forced farmers to till the product into the ground due to its trifle price.

\section{RFERENCES}

AOAC., 1990.Official methods of analysis of Association of Official analytical chemists. 5th Ed. by Kennen Helrich.

Brendan,I.A.Juming,T.andCharlesG.E.1999.Evaluation of the energy efficiency and quality retention for refractance window drying system.Dept.of Biological Systems Eng.Washington stat Univ. Project Report:1-36.

Dennis,R.H and Singh R,P.1981.Food process engineering. Second Ed.AVI Pub.CompanyInc. Wesport Conn.U.S.A:269.

Feng,H.,Tang, J.and Cavalierie,R.P.1999.Combined microwave and sprouted bed drying of diced apples:Effect of drying conditions on kinetics and product temperature,Drying technology.17(10)19811998.

Gehrmann,D.1979.Theoretische experimentelle untersuchungen, Disssertian.Universitat Darmstadt.(C.f.Sjoholm,1982).

Lin, S.H.andAgalloco,J.1979.Degradation kinetics of ascorbic acid. Process Biochemistry J.:22-27.

Jean,A., and Penington, T.1994.Food values portions commonly used.J.B.Lippinott Co. Lib. of Congress Cataloging- 550871:55,267.

Murphy,G.1950.Similitude in engineering . N. Y. The Roland Press Co. :3637.

Rai G.D.1980. Solar energy utilization.1 st. Ed., Pub. By Romesh Chander Khanna.2-8 North market, New Delhi.110006.:58-67,192196. 
Sjoholm,I.1982.Heat and mass transfer in sugar solutions during drying. Eng. and Science in the Food Industry. Edited by Brian M. Mckena. (1): 177-184.

Toledo,R.T.1991.Fudamentals of food process engineering. An AVI book Pub. By Van Nostrand Reinhold.N.Y.10003.ISBN. o-442-239886:133-136.

\section{الملخص العربي \\ نمذجة مجفف انعكاسى لتجفيف طبقة رقيقة من السوائل * مارق حسين غانم}

يهدف البحث الى التوصل لنموذج رياضى للتنبؤ بمعادلة لتجفيف طبقة رقيقة من الأغذية السـائلة

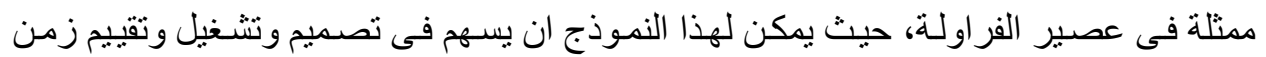

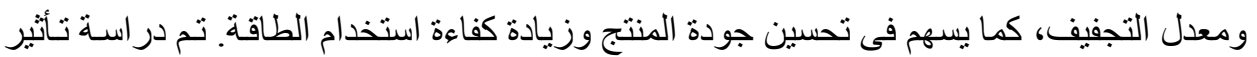

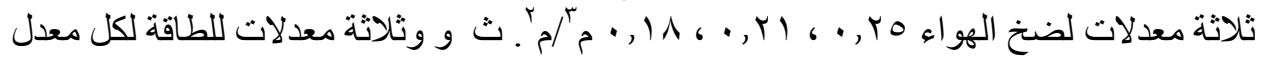

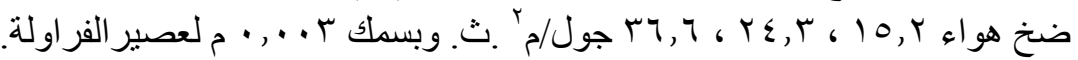

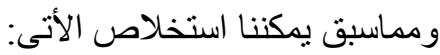

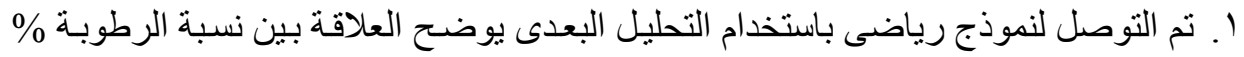

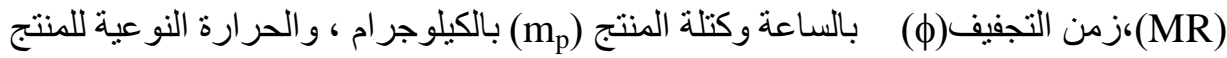

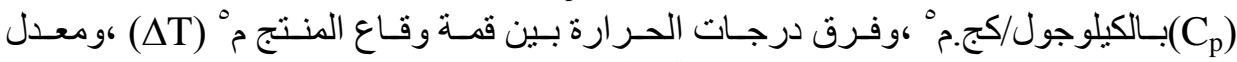

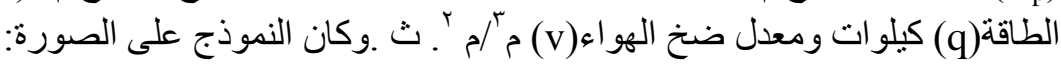

$\mathbf{M R}=\mathbf{e}$

$$
-0.4\left(\frac{m_{p} c_{p} \Delta T}{q \phi}\right)^{0.1}\left(\frac{\lambda}{v \phi}\right)^{0.6}\left(\frac{m_{p} c_{p} \Delta T}{q \phi}\right)^{0.07}
$$

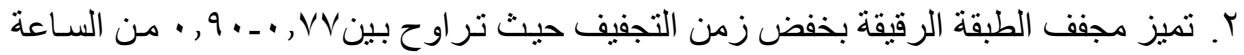

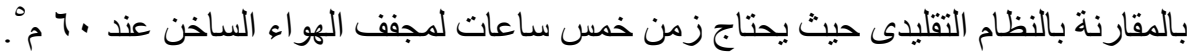

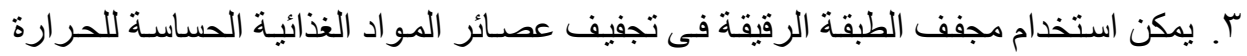

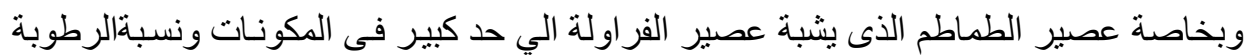

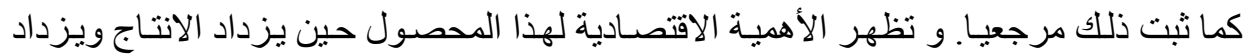

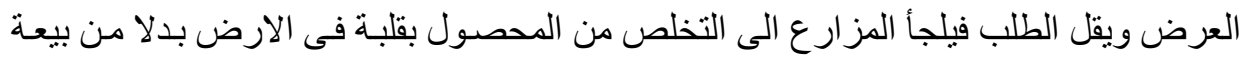
بسعريقل كثير اعن تكلفة انتاجة.

*أستاذ مساعد الهندسة الزر اعية ـ كلية الزر اعة بالقاهرة - جامعة الأزهر. 